\title{
PANDEMI COVID 19: INFLASI DAN PENGANGGURAN DALAM PERSPEKTIF EKONOMI ISLAM
}

\author{
Mauizhotul Hasanah ${ }^{1}$, Safarinda Imani ${ }^{2}$ \\ 1STIS SBI Surbaya, 2Universitas Ibrahimy \\ * mauizhotulh0707@gmail.com, safarinda.imani@gmail.com
}

\begin{abstract}
This study aims to analyze the tradeoff between inflation and unemployment based on an Islamic economic perspective. Inflation and unemployment are important indicators of economic performance and both are major problems that must be controlled immediately because they will have a wide impact on various things, especially during the Covid-19 pandemic conditions. Inflation and unemployment have a negative relationship, the lower the level of unemployment, the higher the inflation rate. One of the causes of inflation is the increased price of goods which results in an increase in production costs. Whereas in Islam the existence of costs is caused by the monopoly of goods or labor, but in an Islamic-based market it is not applied. Therefore Muslim entrepreneurs will not face high costs to meet excess wages because workers get wages that must match the earned productivity. Furthermore, the handling of unemployment affected by the Covid-19 pandemic can be done by maximizing the Islamic economic philanthropic scheme, namely zakat, infaq, shadaqah, and lending on a qardhul hasan basis.
\end{abstract}

Keywords: Inflation, Unemployment, Pandemic Covid-19, Islamic Economic

\section{Abstrak}

Penelitian ini bertujuan untuk menganalisis mengenai tradeoff antara inflasi dan pengangguran berdasarkan perspektif ekonomi Islam. Inflasi dan pengangguran merupakan indikator penting dari kinerja perekonomian dan keduanya sebagai permasalahan utama yang harus segera dikendalikan karena akan berdampak luas bagi berberbagai hal, apalagi pada kondisi pandemi covid-19. Inflasi dan pengangguran memiliki hubungan yang negative, semakin rendahnya tingkat penagngguran maka akan berdampak pada semakin tingginya inflasi. Inflasi tercipta salah satunya disebabkan oleh harga barang yang meningkat berakibat pada kenaikan biaya produksi. 
Sedangkan dalam Islam adanya biaya disebabkan oleh adanya monopoli barang atau tenaga kerja, namun dalam pasar berbasis Islam tidak diterapkan. Oleh karena itu pengusaha muslim tidak akan menghadapi biaya yang tinggi untuk memenuhi upah berlebih karena para pekerja mendapatkan upah harus sesuai dengan perolehan produktifitasnya. Selanjutnya untuk penanganan pengangguran yang terdampak dari pandemic covid-19 dapat dengan memaksimalkan skema filantropi ekonomi Islam yaitu zakat, infaq, shadaqah, dan penyaluran pinjaman dengan berbasis qardhul hasan.

Keywords: Inflasi, Pengangguran, Pandemic Covid-19, Ekonomi Islam

\section{A. PENDAHULUAN}

Konsep kesejahteraan ekonomi merupakan suatu pembahasan terpenting setiap negara, apalagi saat pandemi covid-19 melanda hampir di setiap Negara. Wabah covid-19 berdampak besar dan hampir melumpuhkan perekonomian setiap Negara, begitupula dengan masyarakat Indonesia ${ }^{1}$. Aktivitas perekonomian sangat dibatasi pergerakannya oleh pemerintah, karena angka pandemi Covid-19 yang terus bertambah tinggi. Perekonomian Indonesia kuartal kedua tercatat minus 5,32\%, dan Indonesia resmi mengalami resesi (BPS, 2020). Akibatnya berbagai permasalahan muncul seperti kelangkaan barang, angka pengangguran meningkat, melemahnya sector pariwisata, pembatasan transportasi, dan lain sebagainya.

Setelah diberlakukannya aturan PSBB new normal Indonesia mulai membangun kambali perekonomian yang sudah lumpuh. Membangun perekonmian yang baik merupakan kewajiban setiap Negara, baik melalui pendekatan mikroekonomi maupun makroekonomi. Terdapat indikator penting dari kinerja makroekonomi yang perlu diperhatikan, apalagi indikator ini sangat terdampak covid-19 yaitu inflasi dan pengangguran. Keduaya merupakan permasalahan utama yang harus segara dikendalikan, karena pengendalian inflasi dan pengangguran memiliki peran penting bagi

${ }^{1}$ Syadza Alifa, 'Menganalisa Masalah Sosial Ekonomi Masyarakat Terdampak Covid19', Puspensos, 2020. 
pembangunan ekonomi². Produktivitas yang tinggi, stabilitas harga, dan pengangguran yang rendah merupakan tujuan dari makroekonomi yang diinginkan oleh setiap Negara ${ }^{3}$. Inflasi terbukti menjadi faktor penentu yang signifikan bagi pertumbuhan ekonomi, inflasi yang tinggi akan mengurangi pertumbuhan ekonomi yang menyebabkan lebih sedikit lapangan pekerjaan yang tersedia, dan meningkatkan pengangguran ${ }^{4}$.

Tingkat pengangguran memiliki hubungan yang negatif dengan inflasi. Dikarenakan menurut kurva Philips tingkat inflasi akan menurun jika pengangguran meningkat begitupula sebaliknya ${ }^{5}$. Inflasi merupakan sebuah fenomena moneter, dimana kenaikan harga barang atau komoditas secara menyeluruh dan terus menerus ${ }^{6}$. Berdasarkan teori Keynes bahwa inflasi disebabkan oleh perilaku suatu masyarakat yang ingin hidup di luar batas kemampuan ekonominya7. Adapun naiknya harga barang disamakan dengan menurunnya nilai mata uang ${ }^{8}$. Maka inflasi pun dapat disebut sebagai penurunan nilai mata uang terhadap barang. Pandangan dari teori Keynes bahwa hal yang paling menentukan kestabilan ekonomi nasional adalah permintaan masyarakat, dimana rendahnya kapasitas barang yang diproduksi akan berakibat pada naiknya harga suatu barang yang akan berdampak

${ }^{2}$ Mehrnoosh Mohseni and Feizolah Jouzaryan, 'Examining the Effects of Inflation and Unemployment on Economic Growth in Iran ( 1996-2012 )', Procedia Economics and Finance, 36.16 (2016), 381-89 .

${ }^{3}$ Dolly Singh and Nmp Verma, 'Tradeoff between Inflation and Unemployment in the Short Run: A Case of the Indian Economy', International Finance and Banking, 3.1 (2016), 77-96 .

${ }^{4}$ Nurul Lisani, Raja Masbar, and Vivi Silvia, 'Inflation-Unemployment Trade-Offs In ASEAN-10', Signifikan: Jurnal Ilmu Ekonomi, 9.2 (2020), 241-56.

5 Rabiul Islam and others, 'Determinants of Factors That Affecting Inflation in Malaysia', International Journal of Economics and Financial Issues, 7.2 (2017), 355-64.

${ }_{6}$ Muhammad Ali Nasir, Toan Luu Duc Huynh, and Xuan Vinh Vo, 'Exchange Rate Pass-through \& Management of Inflation Expectations in a Small Open Inflation Targeting Economy', International Review of Economics and Finance, 69.April (2020), 178-88.

7 Salman Al Parisi, 'Determinan Inflasi: Pendekatan Al- Maqrizi Dan Perspektif Manajemen Syariah', Islamic Economics Journal, 4.2 (2018), 217-48.

8 Sugeng Sugeng and others, 'Effects of Foreign Exchange Supply and Demand Dynamics To Rupiah Exchange Rate and Economic Performance', Bulletin of Monetary, Economics and Banking, 12.3 (2010), 289-328. 
inflasi ${ }^{9}$.

Selanjutnya salah satu dampak dari covid-19 yang paling berat yaitu semakin banyaknya pengangguran. Kondisi banyaknya masyarakat yang kehilangan pekerjaan akan berdampak pada psikologis seseorang, karena mereka beranggapan bahwa kehilangan pekerjaan akan menurunkan standar kehidupan. Jika dilihat dari sisi ekonomi ketika banyaknya pengangguran atau kehilangan pekerjaan maka bertepatan dengan hilangnya pendapatan dan akan membatasi akeses sumber daya ekonomi ${ }^{10}$. Selain itu dilihat dari sisi sosial, pengangguran akan berakibat pada banyaknya kejahatan sosial seperti kekerasan, korupsi, pembunuhan, dan lain sebagainya.

Berdasarkan teori Keynes (1946) menyatakan bahwa volume pekerjaan diberikan oleh titik perpotongan antara fungsi permintaan agregat dan fungsi penawaran agregat. Jadi ketika perusahaan mengalami kenaikan biaya maka kenaikan biaya tersebut dikarenakan meningkatnya pengeluaran pemerintah, dimana akan menggeser kurva penawaran ke atas, sehingga menyebabkan pengangguran dan inflasi yang lebih besar. Kebijakan moneter dan kebijakan fiskal dapat menggeser kurva permintaan agregat, oleh karena itu kebijakan moneter dan kebijakan fiskal perekonomian dapat dipindahkan sepanjang kurva philips, dimana suatu titik kurva Philips dengan tingkat pengangguran yang lebih rendah dan inflasi yang lebih tinggi.

Hal ini para ekonom klasik menjadikan kurva Philips sebagai solusi atas tarik ulur antara inflasi dan pengangguran. Namun bagaimana jika di lihat dari perspektif ekonomi Islam? Sedangkan Islam tidak mengadopsi inflasi. Oleh karena itu, tujuan penelitian ini akan membahas mengenai trade off antara inflasi dan penganguran dilihat dari perspektif ekonomi Islam serta bagaimana perspektif ekonomi Islam mengenai pengangguran dan inflasi

\footnotetext{
${ }^{9}$ Islam and others (2017).

${ }^{10}$ Laura Pohlan, 'Unemployment and Social Exclusion', Journal of Economic Behavior and Organization, 164 (2019), 273-99.
} 
yang menjadi dampak dari pandemic covid-19.

\section{B. HASIL DAN PEMBAHASAN}

\section{Pengangguran (Unemployment)}

Pengangguran merupakan sebutan dari mereka yang tidak memiliki pekerjaan atau sedang mencari pekerjaan. Menurut Sakirno (2006) ${ }^{11}$ penganguran adalah suatu keadaan dimana seseorang tergolong ke dalam angkatan kerja yang ingin mendapatkan pekerjaan, namun mereka belum memperoleh pekerjaan tersebut. Kategori pengangguran yaitu mereka yang tidak memiliki pekerjaan pada usia kerja, adapun usia kerja biasanya di atas usia anak-anak dimana seseorang bukan dalam masa sekolah. Tingkat pengangguran terbuka diartikan sebagai persentase jumlah pengangguran terhadap jumlah angkatan kerja ${ }^{12}$. Faktor utama penyebab terjadinya pengangguran yaitu kurangnya pengeluaran agregat. Dimana pengusaha memproduksi barang dan jasa untuk mendapatkan keuntungan. Semakin tinggi permintaan maka akan semakin besar produk yang dihasilkan sehingga perusahaan akan meningkatkan produksinya dan akan membutuhkan tenaga kerja tambahan ${ }^{13}$. Pengangguran berdasarkan penyebabnya dibagi menjadi empat macam Sukirno (2004) yaitu:

a) Pengangguran friksional (normal) merupakan jenis pengangguran yang disebabkan oleh seseorang yang ingin mencari pekerjaan yang lebih baik;

b) Pengangguran siklikal merupakan jenis pengangguran yang disebabkan oleh merosotnya kegiatan ekonomi atau karena kecilnya

11 Sadono Sukirno, Ekonomi Pembangunan (Jakarta: Kencana, 2006).

12 Siti Indayani and Budi Hartono, 'Analisis Pengangguran Dan Pertumbuhan Ekonomi Sebagai Akibat Pandemi Covid-19', Perspektif: Jurnal Ekonomi \& Manajemen Universitas Bina Sarana Informatika, 18.2 (2020), 201-8.

13 Sarastri Mumpuni Ruchba and Fakhry Hadiyan, 'Analysis on Unemployment and Inflation in Indonesia for The Periode of 1980 -2016 Using Philipps Curve Approach', Proceeding of The 3rd International Conference on Accounting, Business E Economics, 2019, 111-22. 
permintaan agregat pada perekonomian dibandingkan penawaran agregatnya;

c) Pengangguran struktural merupakan jenis pengangguran yang disebabkan oleh adanya perubahan struktur kegiatan ekonomi;

d) Pengangguran teknologi merupakan mengangguran yang disebabkan oleh adanya pergantian tenaga manusia oleh teknologi.

Tingkat pengangguran yang mempengaruhi grafitasi perekonomian dalam jangka panjang merupakan tingkat pengangguran alamiah, terdapatnya ketidaksempurnaan pasar tenaga kerja yang membuat mereka kesulitan untuk segera mendapatkan pekerjaan. Adapun menurut Naf'an (2014) ${ }^{14}$ untuk mengatasi pengagguran, yaitu:

a) Kebijakan fiskal yaitu dengan menambah pengeluaran pemerintah dan mengurangi pajak;

b) Kebijakan moneter yaitu dengan menurunkan suku bunga, atau menambah penawaran uang, dan menyediakan kredit untuk kegiatan tertentu.;

c) Kegiatan dalam segi penawaran, yaitu dengan cara mengembangkan infrastruktur, memberi subsidi, mendorong lebih banyaknya investasi, meningkatkan efisiensi administrasi pemerintahan, dan pengurangan pajak perusahaan maupun pajak individu.

Pengangguran dan lapangan pekerjaan merupakan kedua hal yang tidak dapat dipisahkan. Dimana terdapatnya banyaknya lapangan pekerjaan maka dapat mengurangi pengangguran, begitupula sebaliknya dimana semakin sempitnya lapangan pekerjaan maka akan berdampak pada semakin banyaknya pengangguran. Pengangguran merupakan masalah utama bagi keberlangsungannya pembangunan negara. Setiap manusia pada hakikatnya diwajibakan bekerja. Sebagaimana dalam ayat Al-Quran surat al-A'raf ayat 10

${ }^{14}$ Naf'an, Ekonomi Makro Tinjauan Ekonomi Syariah (Yogyakarta: Graha Ilmu, 2014). 
: "Sesungguhnya Kami telah menempatkan kamu sekalian di muka bumi dan Kami adakan bagimu di muka bumi itu (sumber) penghidupan. Amat sedikitlah kamu bersyukur". Konsepsi Islam tentang bekerja merupakan suatu kewajiban agama yang menyeluruh atas setiap muslim (bersifat individual) yang memiliki kemampuan untuk bekerja demi mencapai kebahagiaan individu, keluarga, dan masyarakat 15 .

Namun, jika kondisi masyarakat tidak memiliki pekerjakan karena sulitnya mendapat pekerjaan, sedikitnya lapangan pekerjaan, dan lainnya. Sehingga sudah seharusnya negara menciptakan lapangan pekerjaan yang menjadi tempat untuk mereka demi berlangsungnya berlangsungnya pembangunan suatu negara. Adapun untuk mendapatkan kesejahteraan, Islam memberikan cara yaitu dengan menyediakan lapangan kerja. Sebagaimana Rasulullah saw bersabda: "Seorang Imam adalah pemelihara dan pengatur urusan (rakyat), dan ia akan diminta pertanggung jawaban terhadap urusan rakyatnya" (HR. Bukhari dan Muslim). Menyediakan lapangan kerja merupakan kewajiban bagi setiap negara dan merupakan bagiann dari tanggung jawab nya terhadap pemeliharaan dan urusan rakyatnya ${ }^{16}$. Selain itu, terdapat sebuah riwayat Rasulullah pernah memberikan dua dirham kepada seseorang, kemudian beliau bersabda, "Makanlah dengan satu dirham, sisanya belikan kapak, lalu gunakan untuk bekerja". Hal ini lah yang menjadi dasar bahwa memberikan lapangan pekerjaan merupakan cara untuk mengentaskan kemiskinan dan memberikan kesejahteraan kepada masyarakat.

\section{Teori Inflasi}

Terjadinya penurunan pada nilai suatu unit terhadap komoditas merupakan sebuah fenomena moneter yang disebut sebagai inflasi. Inflasi merupakan keadaan perekonomian yang ditandai oleh kenaikan harga secara

\footnotetext{
15 Armansyah Walian, 'Konsepsi Islam Tentang Kerja Rekonstruksi Terhadap Pemahaman Kerja Seorang Muslim', An Nisa'a, 8.1 (2013), 63-80.

${ }^{16}$ Hady Sutjipto, 'Solusi Islam Terhadap Masalah Ketenagakerjaan', Mimbar: Jurnal Sosial Dan Pembangunan, XIX.4 (2003), 425-44.
} 
terus menerus sehingga berdampak pada menurunnya daya beli ${ }^{17}$. Inflasi adalah kenaikan dalam harga barang dan jasa yang terjadi karena permintaan bertambah besar dibandingkan dengan penawaran barang di pasar ${ }^{18}$. Menurut Al-Maqrizi peristiwa inflasi merupakan sebuah fenomena yang terjadi di kehidupan masyarakat di seluruh dunia sejak dahulu hingga saat ini, dan didefinisikan bahwa inflasi terjadi ketika harga-harga secara umum mengalami kenaikan dan berlangsung secara terus menerus ${ }^{19}$.

Inflasi sebagai suatu fenomena ekonomi yang sering dibahas oleh setiap negara, dan menjadi pertimbangan pemerintah untuk menstabilkan inflasi di negaranya. Dampak dari tingginya inflasi sangat luas terhadap perekonomian negara, seperti pertumbuhan ekonomi, daya saing, stabilitas ekonomi, dan distribusi pendapatan. Tujuan dari menurunkan inflasi pun bukan menjadikan inflasi menjadi nol persen karena hal tersebut bukanlah hal mudah. Berdasarkan para ekonom Islam, inflasi berakibat buruk bagi perekonomian dikarenakan menimbulkan gangguan pada fungsi uang, terutama pada fungsi tabungan, fungsi dari pembayaran di muka, dan fungsi dari unit perhitungan ${ }^{20}$. Sehingga menjadi tugas bagi pemerintah untuk menerapkan kebijakan agar tingkat inflasi dapat stabil. Menurut Karim (2015) 21 inflasi digolongkan berdasarkan penyebabnya, yaitu:

a) Natural inflation dan Human Eror Inflation.

Natural inflation, yaitu inflasi yang terjadi karena sebab alamiah, sehingga manusia pun tidak mempunyai kuasa untuk mencegahnya.

${ }^{17}$ Ambok Pangiuk, 'Inflasi Pada Fenomena Sosial Ekonomi : Pandangan Al- Maqrizi', Kontekstualita, 30.2 (2015), 220-37.

18 Sukirno (2006).

${ }^{19}$ Aziz Septiatin, Mawardi, and Mohammad Ade Khairur Rizki, ‘Pengaruh Inflasi Dan Tingkat Pengangguran Terhadap Pertumbuhan Ekonomi Di Indonesia', I-Economic, 2.1 (2016), $50-65$.

${ }^{20}$ Idris Parakkasi, 'Inflasi Dalam Perspektif Islam', Laa Maisyir, 3.1 (2016), 41-58.

21 Adiwarman A Karim, Ekonomi Makro Islam (Jakarta: PT Raja Grafundo Persada, 2015). 
Sedangkan Human Eror Inflation yaitu inflasi terjadi karena kesalahan yang dilakukan oleh manusia.

b) Expected Inflation dan Unexpected Inflation.

Expected Inflation, yaitu dimana tingkat suku bunga pinjaman riil akan sama dengan tingkat suku bunga pinjaman riil akan sama dengan tingkat suku bunga pinjaman nominal yang dikurangi inflasi. Sedangkan unexpected inflatiom yaitu tingkat suku bunga pinjaman nominal belum terjadi refleksi terhadap efek inflasi.

c) Demand Full dan Cost Push Inflation.

Demand full, yaitu inflasi yang diakibatkan oleh perubahanperubahan yang terjadi pada sisi permintaan agregat (AD) dari suatu barang pada perekonomian. Cost push inflation, yaitu inflasi yang diakibatkan oleh perubahan-perubahan pada sisi penawaran agregat (AS) dari barang pada suatu perekonomian.

d) Spiralling Inflation.

Spiralling inflation, yaitu inflasi yang diakibatkan oleh inflasi yang terjadi sebelumnya, dimana inflasi tersebut disebabkan oleh inflasi sebelumnya juga, dan begitu seterusnya.

e) Imported Inflation dan Domestic Inflation.

Imported inflation, yaitu inflasi yang diakibatkan oleh inflasi yang dialami negara lain dikarenakan harus menjadi price taker dalam pasar perdagangan internasional. Sedangkan domestic inflation, yaitu inflasi yang terjadi hanya di suatu negara dan tidak mempengaruhi negara lain.

Islam sendiri memiliki pandangan mengenai teori inflasi, yaitu bahwa dalam Islam tidak mengenal inflasi karena mata uang dalam islam bersifat stabil dengan menggunakan mata uang dinar dan dirham, hal ini dijelaskan 
oleh Syekh Nabhani (2001)22 bahwa mata uang dinar dan dirham merupakan mata uang yang sesuai dikarenakan beberapa hal salah staunya yaitu Rasulullah telah menetapkan bahwa emas dan perak sebagai mata uang dan dijadikannya sebagai standar mata uang, dan sifat dari mata uang emas dan perak tidak berubah-ubah dan baku. Adapun dalam ekonomi Islam Taqiuddin Ahmad ibn al-Maqrizi (1364M-1441M), yang merupakan salah satu dari murid dari Ibn Khaldun, telah menggolongkan jenis inflasi menjadi dua golongan, yaitu:

a) Natural Inflation

Natural inflation merupakan sebuah inflasi yang disebabkan berdasarkan alamiah yang berakibat pada turunnya penawaran agregat (AS) atau naiknya Permintaan agregat (AD). Sehingga Natural Inflation diartikan sebagai: [1] Terdapat gangguan pada jumlah barang dan jasa (T) yang diproduksi dalam perekonomian. Misalnya, jika T mengalami penurunan, sedangkan $\mathrm{M}$ dan $\mathrm{V}$ tetap, maka $\mathrm{P}$ akan mengalami kenaikan. [2] Adapun naiknya daya beli masyarakat secara riil. Misalnya, nilai ekspor lebih besra dari pada nilai impor, sehingga secara netto terjadinya impor uang yang mengakibatkan pada menurunya $\mathrm{M}$, sehingga apabila $\mathrm{V}$ dan $\mathrm{T}$ tetap maka $\mathrm{P}$ mengalami kenaikan.

Sehingga Natural Inflation dibedakan berdasarkan penyebabnya menjadi dua golongan yaitu:

a) Akibat dari uang yang masuk dari luar negeri terlalu banyak, dimana ekspor mengalami kenaikan sedangkan impor mengalami penurunan sehingga nilai dari net export sangat besar mengakibatkan naiknya permintaan agregat (AD). Adanya positive net export akan menghasilkan keuntungan, sehingga pendapatan dan daya beli

${ }^{22} \mathrm{Naf}^{\prime}$ an (2014). 
masyarakat akan mengalami kenaikan. Hal ini pernah terjadi pada masa pemerintahan Khalifah Umar bin Khattab r.a, dimana pedagang yang berjualan di luar negeri, membeli barangnya dari luar negeri dengan nilai yang lebih rendah dari pada barang-barang yang mereka jual. Kemudian Khalifah Umar melarang penduduk Madinah untuk membeli barang-barang selama 2 hari berturut-turut. Sehingga berakibat pada turunnya permintaan agregat (AD) dalam suatu perekonomian. Setelah itu, tingkat harga pun kembali normal.

b) Akibat dari turunnya tungkat produksi (AS) disebabkan oleh terjadinya paceklik, embargo, dan perang. Adapun kurva AS bergeser ke kiri, yang mengakibatkan kenaikan harga-harga(P). Hal ini pun pernah terjadi pada masa Khalifah Umar bin Khattab r.a, yaitu pada masa paceklik, sehingga mengakibatkan kelangkaan gandum, kemudian Umar melakukan impor gandum dari Fustat ke Mesir sehingga penawaran agregat (AS) terhadap barang di pasar kembali naik, yang berakibat pada turnnya tingkat harga-harga $(\mathrm{P})$.

\section{2) Human Eror Inflation}

Human eror inflation merupakan inflasi yang disebabkan oleh kesalahan manusia sendiri, sesuai dengan surat Ar-Rum ayat 41 yaitu: "Telah nampak kerusakan di darat dan di laut disebabkan karena perbuatan tangan manusia, supaya Allah merasakan kepada mereka sebagian dari (akibat) perbuatan mereka, agar mereka kembali (ke jalan yang benar)". Berdasarkan penyebabnya jenis inflasi ini dikelompokan menjadi tigas jenis yaitu:

a) Corruption and Bad Administration

Ketika merujuk pada persaman $\mathrm{MV}=\mathrm{PT}$ maka tingkat harga $(\mathrm{P})$ akan terganggu oleh korupsi, dikarenakan para produsen akan menaikkan harga jual produksinya untuk membiayai ulah para koruptor yang telah mereka keluarkan. Harga suatu barang akan terdistorsi oleh komponen yang seharusnya tidak ada, sehingga akan 
mengakibatkan tingginya biaya, sehingga akan merugikan masyarakat. Jika melihat ada persamaan AS -AD maka akan terlihat bahwa korupsi dan sistem administrasi pemrintah yang buruk akan menyebabkan pergeseran pada kurva penawaran agregat (AS).

b) Excessive Tax

Pajak yang berlebihan akan menimbulkan akibat yang sama dengan akibat dari korupsi dan buruhnya administrasi pemerintah, yaitu berupa bergesernya kurva penawaran agregat (AS). Selain itu, jika dilihat secara jauh lagi maka pajak yang berlebihan akan mengakibatkan yang disebut dengan efficiency loss atau dead weight loss.

c) Excessive Seignorage

Tindakan seignorage merupakan salah satu penyebab inflasi. Arti seignorage adalah keuntungan dari percetakan koin yang didapatkan dari percetakannya, dimana percetakan tersebut miliki penguasa. Secara umum pemerintah negara-negara barat mempercayai bahwa percetakan uang akan menghasilkan keuntungan bagi pemerintah, hal ini sesuai dengan persamaan sebagai berikut:

Real revenue from printing money $=\frac{\left(M_{t}-M_{t-1}\right)}{P_{t}}=\mu x \frac{M_{t-1}}{P_{t}}$

Dimana $\mu$ adalah tingkat pertumbuhan uang. Ketika nilai $\mu$ tinggi maka akan mengakibatkan tingginya tingkat inflasi (п), sehingga berimplikasi pada nilai nominal yang tinggi dari tingkat suku bunga $(R=r+\Pi)$. Oleh karena itu, tingkat pertumbuhan uang yang tinggi akan menghasilkan tingkat pajak yang lebih tinggi dari pajak memegang uang.

Di sisi lain, Ibn al-Maqrizi berpendapat bahwa mencetak uang berlebih akan mengakibatkan naiknya tingkat harga $(\mathrm{P})$ secara keseluruhan atau disebut sebagai inflasi. Kenaikan harga-harga 
komoditas merupakan kenaikan dalam bentuk jumlah uang, sedangkan jika diukur dengan emas maka harga komoditas jarang mengalami kenaikan. Ibn al-Maqrizi berpendapat bahwa sebaiknya uang dicetak saat dibutuhkan untuk bertransaksi dan dalam bentuk pecahan bernilai kecil.

\section{Hubungan antara Inflasi, Pengangguran, dan Kurva Philips}

Inflasi dan pengangguran merupakan ukuran kinerja perekonomian suatu negara yang penting. Pada tahun 1958 A.W Philips meneliti tentang fenomena antara inflasi dan pengangguran, Ia pun menemukan bahwa terdapat hubungan negatif antara inflasi dan pengangguran, yaitu semakin rendahnya tingat pengangguran, maka akan berdampak pada semakin tingginya tingkat inflasi. Sebaliknya, semakin tingginya tingkat pengangguran maka akan semakin rendahnya tingkat inflasi, dalam hal ini disebut sebagai trade off antara inflasi dan pengangguran. Trade off antara pengangguran dan inflasi seharusnya terdapat dalam jangka pendak, tetapi dalam jangka panjang dianggap tetap ada karena tingkat pengangguran ditentukam oleh kekuatan nyata di pasar tenaga kerja ${ }^{23}$.

Trade off antara inflasi dan pengangguran keduanya memiliki tujuan yang bertentangan. Adapun dampak dari inflasi adalah meningkatnya jumlah pengangguran. Ketika terjadinya kenaikan suatu barang secara terus menerus dan secara menyeluruh maka perusahaan akan banyak mengurangi produksinya, maka dengan alasan efisiensi produsen pun akan mengurangi karyawannya untuk sementara dan ada pula yang memberhentikan karyawnnya. Namun dibeberapa negara berkembang dampak inflasi terhadap lapangan kerja lebih parah karena bersaingan dengan tenaga kerja asing sehingga angka pengangguran sulit untuk dikendalikan

23 A.H.G.M. Spithoven, 'Human Capital Inflation and Unemployment', International Journal of Social Economics, 22.5 (1995), 4-14. 
Nickell, et al (2005) menyatakan bahwa di Ghana, kebijakan moneter dan kebijakan fiskal sudah digunakan untuk mengurangi inflasi ke tingkat kestabilan, sehingga meningkatkan pekerjaan, namun ketidakmampuan pemerintah dalam mengambil kebijakan moneter untuk mengendalikan inflasi dan meningkatkan lapangan pekerjaan sehingga terjadilah sebuah kegagalan. Menurut Nickell (2005) terdapat model yang memiliki implikasi yang luas terhadap pengangguran, yaitu (1) pengangguran dalam jangka pendek dan jangka pajang harus konsisten dengan tingkat permintaan nyata. (2) pada jangka panjan, permintaan riil dan pengangguran umumnya cenderung menuju ke level yang konsisten dengan kestabilan inflasi. (3) mencapai tingkat equilibrium kemudahan untuk mendapatkan pekerjaan, dimana pengaguran disebuaikan dengan lapangan pekerjaan yang tersedia.

Menurut Mankiw (2006) ${ }^{24}$ Ketika para pembuat kebijakan menggerakan perekonomian ke atas sepanjang kurva penawaran kurva ageregat jangka pendek, kemudian menurunkan tingkat pengangguran dan menaikkan tingkat inflasi. Begitu pula sebaliknya jika pembuat kebijakan menggerakkan perekonomian ke bawah permintan agregat pada kurva penawaran agregat jangka pendek, maka pengangguran akan naik dan tingkat inflasi akan mengalami penurunan. Dalam jangka pendek, terdapat hubungan negatif antara inflasi dan pengangguran. Pada setiap waktu, pembuat kebijakan yang mengendalikan permintaan agregat dapat memilih kombinasi inflasi dan pengangguran, yang disebut sebagai kurva Philips jangka pendek.

Porsi kurva Philips jangka pendek tergantung pada tingkat inflasi yang diharapkan. Jika inflasi yang diinginkan mengalami kenaikan, maka kurva tersebut akan bergeser ke atas, sehingga pembuat kebijakan menjadi kurang bernilai, dan inflasi akan lebih tinggi pada seluruh tingkat pengangguran. Trade off jangka pendek, antara inflasi dan pengangguran tergantung pada

${ }^{24}$ N. Gregory Mankiw, Makroekonomi (Jakarta: Erlangga, 2006). 
inflasi yang diharapkan. Kurva tersebut lebih tiggi jika inflasi yang diharapkan lebih tinggi (Mankiw, 2006)25.

\section{Inflasi dan Pengangguran dalam Pandangan Makro Islam}

Inflasi dan pengangguran merupakan permasalahan yang kritis di hampir seluruh Negara, Inflasi dan pengangguran disebut sebagai indicator untuk mengukur kesehatan ekonomi suatu Negara ${ }^{26}$. Tingginya tingkat inflasi dapat menurunkan tingkat kesejahteraan social, begitu pula sebaliknya rendahnya tingkat inflasi akan berpotensi untuk menurunkan perekonomian seperti tingkat pertumbuhan, penurunan kemiskinan, penurunan kesempatan kerja, penurunan kesempatan kerja dan secara bertahap akan mengarah pada resesi27. Keduanya merupakan sebuah instrumen yang bertolak belakang. Islam sendiri memiliki pandangan mengenai inflasi dan penganguran.

Islam tidak mengenal inflasi karena uang yang digunakan dinar dan dirham, yang tak berfluktuasi. Islam pun pada dasarnya mewajibkan setiap umatnya untuk bekerja dalam rangka memenuhi kebutuhan dan kesejahteraan hidupnya. Banyak firman Allah dalam Al-Qur'an yang memotivasi umatnya untuk berkerja, adapun salah satu furman Allah yang berbunyi dalam surat al-Mulk ayat 15 yaitu: "Bejalanlah kalian di segala penjurunya dan makanlah sebagian rezekinya" (Q.S al-Mulk:15). Menurut Metwally (1995) ${ }^{28}$ inflasi yang terjadi karena pergeseran kurva permintaan, sedangkan inflasi yang diakibatkan oleh pergeseran kurva penawaran disebut dengan inflasi dorongan biaya. Inflasi yang disebabkan oleh pergeseran permintaan tidak akan mnghasilkan pengurangan tenaga kerja ke bawah tingkat kesempatan kerja penuh, namun karena adanya biaya maka dapat terjadi juga. Pada ekonomi pasar bebas, inflasi merupakan pergeseran kurva

${ }^{25}$ Mankiw (2006).

${ }^{26}$ Lisani, Masbar, and Silvia (2020).

${ }^{27}$ Dwi Wulandari and others, 'Nexus between Inflation and Unemployment: Evidence from Indonesia', Journal of Asian Finance, Economics and Business, 6.2 (2019), 269-75.

${ }^{28}$ Metwally, Teori Dan Model Ekonomi Islam (Cijantung: Bangkit Daya Insana, 1995). 
permintaan dapat berasal dari sektor riil atau sektor moneter. Sedangkan inflasi terdapat biaya dari ketidaksempurnaan pasar baik dalam permintaan maupun penawaran tenaga kerja.

Terciptanya inflasi salah satunya disebabkan oleh cosh push inflation yaitu inflasi yang disebabkan oleh harga barang-barang yang meningkat diakibatkan dari kenaikan biaya produksi29. Inflasi dengan adanya biaya diasumsikan bahwa penawaran uang berasal dari sector riil. Sehingga adanya biaya pada inflasi disebabkan oleh adanya monopoli suatu barang atau tenaga kerja, hal ini tidak akan terjadi jika pasar sesuai dengan prinsip Islam. Dikarenakan Islam melarang untuk pemusatan kekuatan pasar pada sekelompok orang. Dengan demikian, jika penerapan ekonomi Islam diaplikasikan maka inflasi dengan adanya biaya tidak aka nada karena Islam melarang kekuasaan dalam bentuk monopoli pasar. Disamping itu, Islam pun tidak membolehkan adanya serikat pekerja yang terlalu kuat sehingga dapat memonopoli penawaran tenaga kerja.

Adanya konsep berbasis ekonomi Islam para pengusaha muslim tidak akan menghadapi biaya yang tinggi untuk memenuhi tuntutan upah yang berlebih, karena para pekerja mendapatkan upah harus sesuai dengan perolehan produktifitasnya. Sehingga dalam kerangka Islam, kurva penawaran agregat tidak akan bergeser ke kiri, dikarenakan tidak adanya kekuatan monopoli. Dengan demikian kemungkinan inflasi karena pengangguran tidak akan terjadi dalam ekonomi Islam, sedangkan inflasi yang menggeser permintaan yang dapat terjadi dalam ekonomi Islam. Namun, inflasi yang tidak berasal dari sektor moneter, yang mengasumsikan bahwa penawaran uang dalam ekonomi Islam akan berkembang dengan seimbang dengan tingkat pertumbuhan pendapatan nasional. Sehingga perubahan pada permintaan agregat hanya berasar dari sektor riil.

29 Armayanti and Cut Zakia Rizki, 'Pengaruh Sektor Riil Dan Sektor Keuangan Terhadap Inflasi Di Indonesia', Jurnal Ilmiah Mahasiswa (JIM), 2.1 (2017), 73-83. 
Adapun diasumsikan bahwa ekonomi berada pada kesempatan kerja penuh dan karena suatu alasan tertentu pemerintah memutuskan untuk menaikkan pengeluaran, melalui kenaikan pajak pendapatan yang menyeimbangkan dengan pengeluaran. Hal ini berakibat pada bergesernya kurva investasi dan kurva tabungan. Dalam hal ini pergeseran kedua kurva tersebut berakibat pada pergeseran kurva ISU. Terdapat dua upaya untuk menstabilkan inflasi dalam ekonomi Islam, yaitu (1) melalui kenaikan tingkat biaya atas pendapatan perorangan, mengakibatkan kurva konsumsi bergeser ke bawah yang menyebabkan permintaan agregat mengalami penurunan sehingga mencapai keseimbangan kesempatan kerja penuh. (2) menggunakan cadangan yang tersimpan pada baitul mal, dengan cara menggunakan hasil zakat atau pajak yang tidak dibelanjakan pada periode tertentu. Hal ini jumlah surplus selama periode defisit dan depresi dapat du tetapkan sesuai dengan pengamalam. Dengan demikian akan menghasilkan stabilitas ekonomi yang tinggi ${ }^{30}$.

Di sisi lain kondisi saat ini yang terdampak pandemic covid-19 maka banyak masyarakat Indonesia yang mengalami pengangguran. Pengangguran yang terjadi saat kondisi covid-19 termasuk pada jenis pengangguran siklikal disebabkan karena merosotnya kegiatan ekonomi atau kondisi ekonomi yang mengalami resesi. Sejak munculnya covid-19 pemerintah terus berupaya untuk meminimalisir penyebaran wabah ini dengan menerapkan peraturan 3 M yaitu memakai masker, mencuci tangan, dan menjaga jarak (physical distancing). Sejalan dengan usaha tersebut masyarakat lebih banyak melakukan kegiatan di dalam rumah baik sekolah, bekerja maupun melakukan aktivitas ekonomi. Sehingga berdampak pada penurunan aktivitas perekonomian yang berujung pada jumlah produksi yang menurun pula dan

30 Metwally (1995). 
banyaknya tenaga kerja yang diberhentikan. Oleh karena itu, banyak muncul pengangguran yang baru baik permanen maupun non-permanen.

Penanganan dari munculnya pengangguran yang baru ini dapat dengan memaksimalkan skema filantropi ekonomi Islam seperti (1) memberikan bantuan langsung khusunya untuk orang miskin yang sangat terdampak pandemic covid-19, yaitu berasal dari zakat, infaq, dan shadaqah. (2) mengembangkan teknologi berbasis syariah seperti membuat aplikasi market place atau e-commerce yang sudah ada, di buat tempat untuk masyarakat yang memiliki kemampuan lebih untuk menyalurkan zakat, infaq, dan shadaqah disetiap transaksinya walaupun dengan nominal yang kecil. (3) Memberikan pinjaman dari dana qardhul hasan yaitu pinjaman yang tidak mengambil keuntungan apapun namun tetap menekankan untuk membayar kembali pinjaman yang telah diberikan.

\section{KESIMPULAN}

Penelitian ini membahas mengenai tradeoff antara inflasi dan pengangguran, yang bertujuan untuk menganalisa bagaimana tradeoff antara inflasi dan pengangguran dengan perspektif ekonomi Islam. Inflasi dan pengangguran merupakan indikator penting dari kinerja perekonmian yang perlu diperhatikan. Keduanya disebut sebagai permaslaahan utama yang harus segera dikendalikan karena akan berdampak luas bagi semua hal apalagi dengan kondisi pandemic covid-19. Trade off antara inflasi dan pengangguran keduanya memiliki tujuan yang bertentangan. Semakin rendahnya tingkat pengangguran, maka akan berdampak pada semakin tingginya tingkat inflasi. Sebaliknya, semakin tingginya tingkat pengangguran maka akan semakin rendahnya tingkat inflasi, dalam hal ini disebut sebagai trade off antara inflasi dan pengangguran.

Inflasi tercipta salah satunya disebabkan oleh harga barang yang 
meningkat berakibat pada kenaikan biaya produksi. Inflasi dengan adanya biaya diasumsikan bahwa penawaran uang berasal dari sector riil. Sehingga adanya biaya inflasi disebabkan oleh adanya monopoli barang atau tenaga kerja, namun jika pasar sesuai dengan prinsip Islam hal tersebut tidak akan terjadi karena Islam melarang pemusatan kekuatan pasar oleh sekelompok orang. Sehingga para pengusaha muslim tidak akan menghadapi biaya yang tinggi untuk memenuhi tuntutan upah yang berlebih, karena para pekerja mendapatkan upah harus sesuai dengan perolehan produktifitasnya. Sehingga kurva penawaran agregat tidak akan bergeser ke kiri, dikarenakan tidak adanya kekuatan monopoli. Selanjutnya untuk penanganan pengangguran yang terdampak dari pandemic covid-19 dapat dengan memaksimalkan skema filantropi ekonomi Islam yaitu zakat, infaq, shadaqah, dan penyaluran pinjaman dengan berbasis qardhul hasan. 


\section{DAFTAR PUSTAKA}

Alifa, Syadza, ‘Menganalisa Masalah Sosial Ekonomi Masyarakat Terdampak Covid-19', Puspensos, 2020

Armayanti, and Cut Zakia Rizki, 'Pengaruh Sektor Riil Dan Sektor Keuangan Terhadap Inflasi Di Indonesia', Jurnal Ilmiah Mahasiswa (JIM), 2.1 (2017), $73-83$

Indayani, Siti, and Budi Hartono, 'Analisis Pengangguran Dan Pertumbuhan Ekonomi Sebagai Akibat Pandemi Covid-19', Perspektif: Jurnal Ekonomi E Manajemen Universitas Bina Sarana Informatika, 18.2 (2020), 201-8

Islam, Rabiul, Ahmad Bashawir, Abdul Ghani, Emil Mahyudin, and Narmatha Manickam, 'Determinants of Factors That Affecting Inflation in Malaysia', International Journal of Economics and Financial Issues, 7.2 (2017), 355-64 Karim, Adiwarman A, Ekonomi Makro Islam (Jakarta: PT Raja Grafundo Persada, 2015)

Lisani, Nurul, Raja Masbar, and Vivi Silvia, 'Inflation-Unemployment TradeOffs In ASEAN-10', Signifikan: Jurnal Ilmu Ekonomi, 9.2 (2020), 241-56

Mankiw, N. Gregory, Makroekonomi (Jakarta: Erlangga, 2006)

Metwally, Teori Dan Model Ekonomi Islam (Cijantung: Bangkit Daya Insana, 1995)

Mohseni, Mehrnoosh, and Feizolah Jouzaryan, 'Examining the Effects of Inflation and Unemployment on Economic Growth in Iran (1996-2012 )', Procedia Economics and Finance, 36.16 (2016), 381-89 <https://doi.org/10.1016/S2212-5671(16)30050-8>

Naf'an, Ekonomi Makro Tinjauan Ekonomi Syariah (Yogyakarta: Graha Ilmi, 2014)

Nasir, Muhammad Ali, Toan Luu Duc Huynh, and Xuan Vinh Vo, 'Exchange Rate Pass-through \& Management of Inflation Expectations in a Small Open Inflation Targeting Economy', International Review of Economics and 
Finance, 69.April (2020), 178-88

<https://doi.org/10.1016/j.iref.2020.04.010>

Pangiuk, Ambok, 'Inflasi Pada Fenomena Sosial Ekonomi : Pandangan Al-

Maqrizi', Kontekstualita, 30.2 (2015), 220-37

Parakkasi, Idris, 'Inflasi Dalam Perspektif Islam', Laa Maisyir, 3.1 (2016), 41-58

Parisi, Salman Al, ‘Determinan Inflasi : Pendekatan Al- Maqrizi Dan Perspektif

Manajemen Syariah', Islamic Economics Journal, 4.2 (2018), 217-48

Pohlan, Laura, 'Unemployment and Social Exclusion', Journal of Economic

Behavior and Organization, 164 (2019), 273-99

<https://doi.org/10.1016/j.jebo.2019.06.006>

Ruchba, Sarastri Mumpuni, and Fakhry Hadiyan, 'Analysis on

Unemployment and Inflation in Indonesia for The Periode of 1980 -2016

Using Philipps Curve Approach', Proceeding of The 3rd International

Conference on Accounting, Business E Economics, 2019, 111-22

Septiatin, Aziz, Mawardi, and Mohammad Ade Khairur Rizki, 'Pengaruh

Inflasi Dan Tingkat Pengangguran Terhadap Pertumbuhan Ekonomi Di

Indonesia', I-Economic, 2.1 (2016), 50-65

Singh, Dolly, and Nmp Verma, 'Tradeoff between Inflation and

Unemployment in the Short Run : A Case of the Indian Economy',

International Finance and Banking, 3.1 (2016), 77-96

<https://doi.org/10.5296/ifb.v3i1.9378>

Spithoven, A.H.G.M., 'Human Capital Inflation and Unemployment',

International Journal of Social Economics, 22.5 (1995), 4-14

<https://doi.org/10.1108/03068299510087895>

Sugeng, Sugeng, M. Noor Nugroho, Ibrahim Ibrahim, and Yanfitri Yanfitri,

'Effects of Foreign Exchange Supply and Demand Dynamics To Rupiah

Exchange Rate and Economic Performance', Bulletin of Monetary,

Economics and Banking, 12.3 (2010), 289-328

<https://doi.org/10.21098/bemp.v12i3.374> 
Pandemi Covid-19: Inflasi dan Pengangguran

Sukirno, Sadono, Ekonomi Pembangunan (Jakarta: Kencana, 2006)

Sutjipto, Hady, 'Solusi Islam Terhadap Masalah Ketenagakerjaan', Mimbar:

Jurnal Sosial Dan Pembangunan, XIX.4 (2003), 425-44

Walian, Armansyah, 'Konsepsi Islam Tentang Kerja Rekonstruksi Terhadap

Pemahaman Kerja Seorang Muslim', An Nisa'a, 8.1 (2013), 63-80

Wulandari, Dwi, Sugeng Hadi Utomo, Bagus Shandy Narmaditya, and

Mahirah Kamaludin, 'Nexus between Inflation and Unemployment:

Evidence from Indonesia', Journal of Asian Finance, Economics and Business,

6.2 (2019), 269-75 <https:/ / doi.org/10.13106/jafeb.2019.vol6.no2.269> 